\title{
What is professional development, how does it occur in individuals, and how may it be used by educational leaders and managers for the purpose of school improvement? ${ }^{1}$
}

\author{
Rafael Mitchell, School of Education, University of Leicester, Leicester, UK \\ rm372@le.ac.uk
}

\begin{abstract}
This article considers the nature of professional development, how it occurs in individuals, and how educational leaders and managers can facilitate professional development for the purpose of school improvement. Social theories of learning provide compelling explanations of the conditions through which professional development occurs in and among individuals within a community of practice. Research into professional learning communities suggests ways forward for educational leaders and managers to foster environments in which individual and organisational learning is optimised through collaboration and shared leadership.
\end{abstract}

Keywords: professional development; professional learning community; school improvement

\section{Introduction}

Over the last three decades, research in the field of School Effectiveness and School Improvement (SESI) has found what people have probably suspected for a long time - that the quality of teaching is a critical factor influencing students' learning (Chapman 2012). This naturally provokes educational leaders and theorists to wonder how the quality of teaching might be enhanced to improve student learning and achievement. To consider possible answers to this question, this article draws from international theories and research. However, before attention can be given to this area it is important to first consider what is meant by professional development, and how it occurs in individuals. Following this, attention will be given to the leadership and management issue of using professional development as a means of school improvement.

\section{What is professional development?}

This section considers a range of definitions of professional development with the aim of reaching a single, conceptually clear definition for the purpose of this article. Key to this task is to sift and evaluate competing definitions of professional development, explore its relationship to professionalism, and consider it alongside notions of continuing professional development (CPD).

\section{Professionalism and the teaching profession}

The word 'profession' derives from the Latin profiteri, to declare publicly, since a profession is an occupation in which one publicly declares a skill. This broad understanding of 'profession' has not always been so inclusive; as recently as the 1960s many sociologists did not regard teaching as a profession (Whitty 2000), while educational theorists such as Hoyle (in Villegas-Reimers 2003) challenge the extent to which teaching is properly regarded as a profession, on the grounds that its knowledge base is an indeterminate mixture of

\footnotetext{
${ }^{1}$ To cite this article: Rafael Mitchell (2013): What is professional development, how does it occur in individuals, and how may it be used by educational leaders and managers for the purpose of school improvement?, Professional Development in Education, 39:3, 387-400.
} 
pedagogy, subject knowledge and practice - and as such could be derived without the specific training required of a profession. However, given the culturally constructed nature of professions, it is probably enough that teaching is widely considered to be a profession. As Villegas-Reimers (2003) argues, it is precisely this growing international acceptance of teaching as a profession that has led to the shift in designation from 'teacher training' to 'teacher professional development'.

Theorists (for example, Day and Sachs 2004, Evans 2008, 2011) have highlighted the link between professional development and professionalism. Evans conceptualises professionalism as 'an ideologically-, attitudinally-, intellectually and epistemologically-based stance' (2008, p. 26), which is 'consistent with commonly-held consensual delineations of a specific profession' (2008, p. 29). Thus professionalism reflects the individual teacher's ideas, values and beliefs, and encompasses the plurality of all such individual perspectives, rather than a set of externally imposed expectations. One tension in this conceptualisation is the extent to which professionalism is individually or consensually derived. Elsewhere, Evans (2011) argues for the redundancy of the term 'unprofessional', yet it seems that this word may have descriptive power in cases where an individual's beliefs or actions do not reflect the consensus.

Day and Sachs identify two discourses of professionalism: managerial and democratic - the former associated with reform initiatives, compliance and economic efficiency, and the latter more activist in nature, emphasising 'collaborative, cooperative action between teachers and other educational stakeholders' (2004, p. 7). Aligned with the managerial discourse of professionalism, which privileges external regulation, systemic and political ends (Day and Sachs 2004), are governmental attempts to change teachers' practice through the setting of professional standards. Evans (2011) points out that efforts to 'shape' teachers' professionalism invariably focus on behavioural aspects of practice, while ignoring the 'phenomenology of change' (Fullan 2007) in individual teachers, and failing to recognise that any modifications in professionalism entail a commensurate development as a professional. Indeed, for Evans, 'the enhancement of individuals' professionalism' (2011, p. 864) is a necessary component of professional development.

\section{Professional development and CPD}

CPD has been defined as, 'The continuation of a teacher's professional development beyond their initial training, qualification, and induction' (Stevenson 2010). This definition suggests that professional development takes place during initial teacher training, and CPD is the extension of such development after the award of a qualification. However, this straightforward definition belies the reality of what has been deemed an 'ambiguous and contested concept' for which 'confusion is apparent in the wide range of opinions on and attitudes to [both its] aims and benefits' (Friedman and Phillips 2004, p. 370).

CPD has been hailed as an essential element of teachers' practice to maintain and improve standards in the face of expanded educational provision and increasing globalisation (for example, Ushie 2009). This is doubtless due, in part, to the endorsement of CPD by influential supranational organisations such as the OECD and the World Bank. For example, in a paper for the OECD, Coolahan appears to argue that the primary purpose of teachers' professional development is to meet the needs of globalisation: 'the teaching profession must adapt a great deal so that it can act in a constructive manner within a fast-changing society' (Coolahan 2002, p. 9). Coolahan situates CPD within the lifelong learning agenda (Fraser et al. 2007), although this is a rather woolly neoliberal concept that has been attacked by Coffield (2003 cited in Fraser et al. 2007) for its 'conceptual vagueness'.

\section{Purposes and definitions}

It is possible to further explore the quiddity, or essential nature, of professional development by its perceived purpose, desired outcomes or aims. Guskey identifies three main goals of 
professional development: 'change in the classroom practices of teachers, change in their attitudes and beliefs, and change in the learning outcomes of students' (2002, p. 383). While the first two goals are relatively unassailable, the primacy of student 'learning outcomes' might be culturally dependent. Lumby et al. (2008) argue that in certain contexts improved learning outcomes might be secondary to other aims, and this is supported by my experience of teachers' CPD in Ethiopia, which uses this as a means of emphasising national aims such as gender parity, HIV prevention and the promotion of environmental and civic responsibility.

Day's definition of professional development is, 'the process by which [...] teachers review, renew and extend their commitment as change agents to the moral purposes of teaching' (2004, p. 13). It is, in my opinion, rather appealing to consider the moral purposes of teaching in a definition of professional development. However, it is arguably unnecessary. Begley identifies three transcendent moral foundations for education - its aesthetic, economic and ideological purposes (in Lumby et al. 2008). If education is inherently moral, as Day also seems to believe, then morality does not require specific attention in a definition of teachers' professional development - any more than it does in a definition of learning or assessment.

While not offering a stipulative definition of professional development, Fraser et al. distinguish it from teacher learning, which they understand as 'processes that [...] result in specific changes in the professional knowledge, skills, attitudes, beliefs or actions of teachers', while professional development refers to 'broader changes that may take place over a longer period of time' (2007, p. 157). In other words, professional development is the outcome of multiple 'specific changes' accrued through teacher learning. Evans' definition of professional development also includes time as a dimension, in that it is 'the process whereby people's professionalism may be considered to be enhanced, with a degree of permanence that exceeds transitoriness' (2011, p. 867). While both of these definitions contain time as a condition, neither succeeds in clarifying this dimension. That changes necessarily take place in time is self-evident, as stated by Aristotle: 'Not only do we measure change by time, but we also measure time by change, because they are determined by each other' (Aristotle et al. 1999, p. 109). In the first definition, 'broader changes' occur over a 'longer period of time', while in the second what might amount to a single change has a longer duration. Yet no measurement for time is offered beyond Fraser et al.'s flimsy comparative ('longer') and Evans' paradoxical 'degree of permanence that exceeds transitoriness'. In the absence of clarity, it is better to dispense with this time element altogether.

Having considered professional development in relation to CPD, its contested nature and aims, I offer my personal definition, which does not refer to morality or duration as conditions, or improved learning outcomes as a goal - as the relevance of these factors depends upon the context in which it is enacted. My current definition of professional development is 'the process whereby an individual acquires or enhances the skills, knowledge and/or attitudes for improved practice'. This definition is offered with the understanding that Evans' conception of 'professionalism' is reflected in the word 'practice', as it is consensually defined; and that if, as Begley and Day assert, teaching serves a moral purpose, then the pursuance of this purpose is necessarily a feature of one's practice.

\section{How does professional development occur in individuals?}

There is broad agreement that a wide range of activities can lead to professional development in individuals, from reflection (Day 1993) to conversations (Haigh 2005) and storytelling (Ball 2009), peer-coaching (Zwart et al. 2007), and the daily engagement with the job at hand (Eraut 2004). However, there is a lack of research into and understanding of how professional development occurs in individuals, while at work (Eraut 1994), through 
interactions with more experienced practitioners (Lave and Wenger 1999) and participation in CPD programmes (Borko 2004). Domains of professional development in individuals Before exploring the leading theories of how professional development occurs in individuals, it is worth considering the domains in which an individual may develop professionally. Rodgers describes adult learning as 'making changes - in our thinking, knowing, feeling and doing' (in Mortimore 1999), and these cognitive, intellectual, attitudinal and behavioural elements are present in Evans' taxonomy of professional development (Figure 1).

It is debatable whether the separation of the intellectual and behavioural domains is as clear as Evans' componential structure suggests. The competential sub-component, which refers to the ability to do something (such as, for example, implementing a seating plan), necessarily includes comprehensive and motivational dimensions. Indeed, it is only the combination of these dimensions that can result in competency. Eraut (1994) denies that professional qualities or attributes can exist outside professional practice or performance: "knowledge ... does not become part of professional knowledge unless and until it has been used for a professional purpose' (1994, p. 120). It follows, then, that intellectual and attitudinal qualities cannot be deemed 'professional' outside their performance or enactment, which necessarily includes all three domains. If questions might remain about the precise configuration of the elements in Figure 1, the list appears to be comprehensive, in the sense that nothing appears to have been omitted.
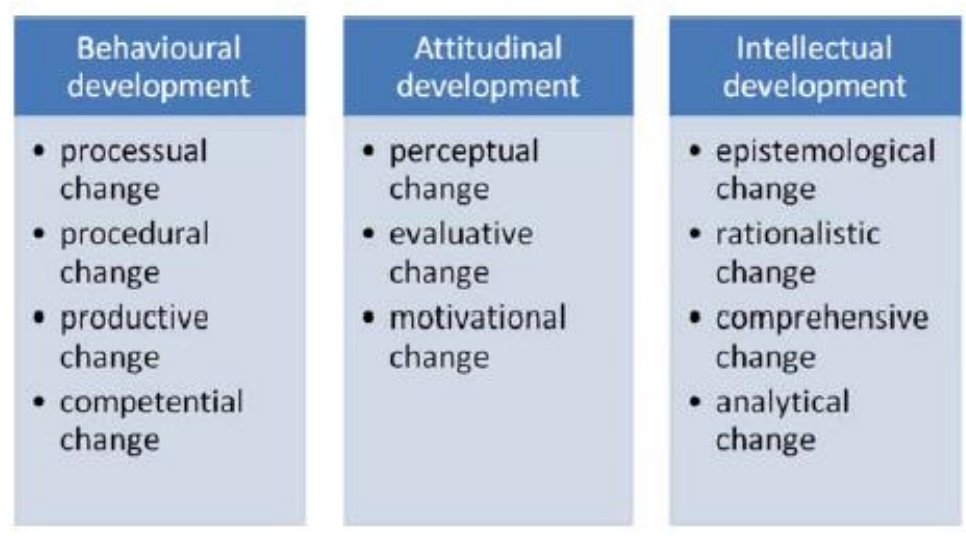

Figure 1. Componential structure of professional development. Source: Adapted from Evans (2011).

\section{Experience, learning and development}

In exploring how professionals acquire or enhance skills, knowledge and/or attitudes for improved practice, it is necessary to consider how and under what conditions they learn. Knowles proposes 'andragogy' as a theory of adults' learning, arguing that in comparison with children adults have greater self-direction, a wider and more varied pool of experience to draw from, and approach learning for practical solutions, 'in order to perform a task [or] solve a problem' (Knowles 1984, p.12). His work has been criticised for its false distinction between the cognitive processes in adults and children, and the lack of clarity as to whether andragogy is a theory of learning or teaching (Hartree 1984). More recent work on adult learning also emphasises agency, holding that adults' personal characteristics, contexts and motives will impact upon what, how and why they choose to learn (Mortimore 1999, p. 177). This bland, seemingly obvious assertion masks a more complex reality: the majority of learning in the workplace is involuntary, imperceptible and inarticulable (Eraut 1994). 
Far from learning being a matter of choice, Eraut argues that it is the inevitable outcome of the continuous engagement with new situations, problems and cases in the workplace.

However, such involuntary learning does not necessarily make a significant contribution to an individual's professional knowledge base or theory of practice, 'unless the case is regarded as special rather than routine and time is set aside to deliberate upon its significance' (1994, p. 10). To clarify, learning will happen with or without volition, but significant professional learning is affected by the attributes and inclination of the individual: 'thus, according to the disposition of individual professionals and the conditions under which they work, their knowledge base may be relatively static or developing quite rapidly' (Eraut 1994, p. 10). Eraut's observation supports Hoyle's hypothetical distinction between restricted and extended professionals, the former privatist, intuitive and guided by prior experience, and the latter collegial, rationally seeking to improve practice (Hoyle in Johnson and Maclean 2008). Through daily engagement in practice, professional development occurs in both through the accumulation of experiences adding to the comprehensive sub-component of intellectual development (see Figure 1). However, by Eraut's argument, reflection gives access to enhanced learning and professional development. This position is challenged by Day (1993), who sees 'reflection as a necessary but not sufficient condition for learning', which additionally requires 'confrontation ... challenge and support' (Day 1993, p. 88). Day also distinguishes between reflection at the level of everyday planning and action, and 'analytic reflection' for ethical justification. This conflict arises from different conceptions of 'learning', which for Eraut may occur 'implicitly' through the involuntary accumulation of experiences, while for Day it appears to be a process of growing self-awareness, of which 'reflection is an essential part' (1993, p. 84) - although his position is far from clear.

Eraut interprets 'informal learning' as 'learning that takes place in the spaces surrounding [workplace] activities' (2004, p. 247), which 'involves a combination of learning from other people and learning from personal experience, often both together' (2004, p. 248). He identifies three categories for informal learning:

- Implicit learning - which occurs without a conscious attempt to learn, or an explicit understanding of what it is that has been learned.

- Reactive learning - which takes place in action, in response to a situation.

- Deliberative learning - which is goal-oriented, and includes an element of time allocation. (Eraut 2004, p. 250)

For Eraut, all three types of learning occur daily, whether an individual is aware of it or not. In acting upon such informal learning, an individual is susceptible to the biases of episodic memory, which allows that 'unusual incidents are more easily remembered than everyday behaviour' (2004, p. 254). For this reason, he argues, the challenge for professionals is to exert greater 'critical control' over their learning, which entails 'considerable self-awareness and a strong disposition to monitor one's action and cross-check by collecting additional evidence in a more systematic manner with greater precautions against bias' (Eraut 2004, p. 255). The form of critical control proposed by Eraut seems consistent with double-loop reflection (see Figure 2).

While such techniques can maximise learning from experience, leading to perceptual, comprehensive and other forms of professional development, the absence of critical reflection, and the failure to acknowledge the teacher as a learner, can restrict learning from experience and impoverish an individual's professional development (Hoekstra et al. 2007). 


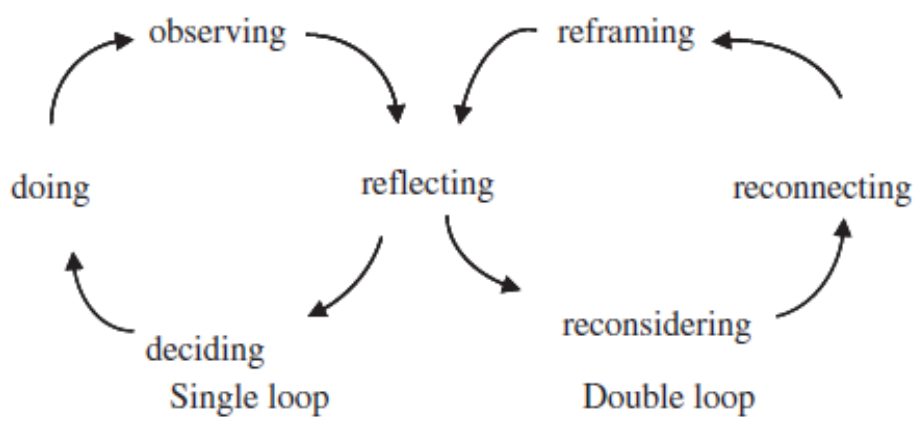

Figure 2. Double-loop reflection.

Source: Adapted from Senge (2000, p. 96).

\section{A social theory of learning}

Lave and Wenger propose that learning is a 'situated activity', in which:

learners ... participate in communities of practitioners [and] mastery of knowledge and skill requires newcomers to move towards full participation in the sociocultural practice of a community. (Lave and Wenger 1991, p. 29)

In Communities of Practice, Wenger (1998) argues that learning is not an individual process, separate from any other human activity, which may be considered in isolation; rather, it should be seen in the context of 'lived experience of participating in the world' $(1998$, p. 3). His theory places learners as 'active participants in the practices of social communities and constructing identities in relation to these communities' (1998, p. 4). Through teaching, a teacher engages in a community of practice with consensually accepted, 'language, tools, documents, images, symbols, well-defined roles ... tacit conventions, subtle cues, untold rules of thumb ... underlying assumptions and shared world views' (Wenger 1998, p. 47). As a teacher engages in the practices of his or her professional community, he or she becomes a fuller participant in that community, thereby acquiring or enhancing the skills, knowledge and/or attitudes for improved practice.

Social theories of learning have led to a questioning of the extent to which learning (and consequently professional development) can be said to be taking place inside the individual. As Kelly (2006) points out, the implication is that "both coming to know and knowing-inpractice [are] processes which, rather than lying entirely with the individual, are distributed across all participants in professional practice' (Kelly 2006, p. 509).

\section{Complex and multidimensional professional development}

As discussed previously, if Figure 1 presents discrete domains and sub-components of professional development, then this is for the purpose of conceptualisation and analysis. In reality, it is not so easy to separate 'the integrated and adaptive use of many different kinds of knowledge and skill' in a teacher's performance (Eraut 2004 , p. 257). If this is true of an individual's practice, then it is equally so for his or her professional development. Guskey's (2002) model for professional development serves as an example of this (see Figure 3 ).

The sequence in Figure 3 has been challenged by evidence that changes in teachers' beliefs can pre-empt changes in practice (Richardson and Placier in Zwart et al. 2007); however, what cannot be disputed is that this model entails multidimensional change - in the behavioural, attitudinal and intellectual domains of Figure 1. This position is supported by the work of Hoekstra et al. which finds that 'the interrelatedness of cognitive, affective, motivational and behavioural aspects in classroom teaching suggests that real change can 


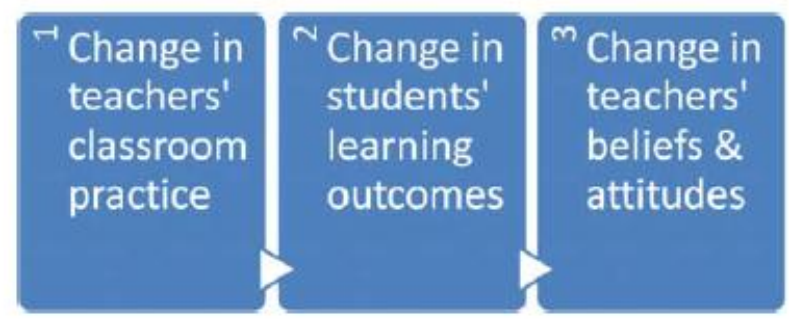

Figure 3. Model of professional development. Source: Adapted from Guskey (2002).

only occur when all of these four aspects are addressed' (2007, p. 204). Eraut (2004) asserts that it is the emotional aspects of professional work that are most frequently neglected, and Evans (2011) agrees - charging the UK Government with a 'lop-sided' approach to professional standards for teachers, which focuses on behavioural over attitudinal dimensions.

Extending this argument beyond the individual, Opfer and Pedder (2011) argue that professional development results from a large number of dynamic factors including biological, normative, institutional, historical - which are neither limitless nor random, but certainly complex. A major flaw with research into teachers' professional development, they argue, is that it focuses on individual teachers or specific programmes or activities, ignoring how these factors interact with the wider complex system. They contend that it is impossible to understand teacher learning except as a result of nested systems:

teacher learning must be conceptualised as a complex system rather than as an event... various dynamics [are] at work in social behaviour and these interact and combine in different ways such that even the simplest decisions can have multiple causal pathways. (Opfer and Pedder 2011, p. 378)

This complex perspective on professional development is consistent with the notion that exactly how such changes occur in individuals is currently 'a known unknown'. Following her extensive review of research in the field, Borko (2004) also concedes that it is still not known why teachers develop at different rates and to different capacities, and why some areas of practice are more amenable to change than others. While conceding this point, the work of the social learning theorists discussed in this section does provide a fairly consistent picture $f$ the means and conditions whereby individuals develop professionally. The next section considers how these concepts can inform educational leaders' efforts towards school improvement.

\section{How may professional development be used by educational leaders and managers for the purpose of school improvement?}

\section{School improvement and leadership}

The term 'school improvement' should not be used uncritically, as it means different things to different people. As mentioned previously, Day and Sachs (2004) distinguish between managerial and democratic conceptions of professionalism. From the perspective of the former, school improvement is associated with notions of effectiveness and efficiency, in which teachers are cast as technicians, and there is an unquestioning acceptance that policies, standards and curricula are in a constant state of revision. The second headline figure on an Ofsted inspection report is a rating of a school's capacity for 'sustained improvement' as a key performance indicator (for example, Ofsted 2010). The term 'school improvement' is often paired with 'school effectiveness' to form SESI, a tradition that many associate with a general trend towards the erosion of teachers' professional autonomy (Slee 
et al. 1998), the imposition of prescriptive standards from above, and an unsustainable 'managerial short-termism' (Davies 2007). Understandings of school improvement have developed since the 1980s, when the OECD defined it as a 'sustained effort aimed at change in learning conditions [...] with the ultimate aim of accomplishing educational goals more effectively' (in Chapman 2012, p. 29; emphasis added). By the mid-1990s, Hopkins understood school improvement to involve, 'raising student achievement through focusing on the teaching and learning processes ... [and] strategies for improving the school's capacity for providing quality education in times of change' (in Chapman 2012, p. 29; emphasis added). For reasons given earlier, I find the phrase 'times of change' to be problematic if not tautological, so this section will focus on school improvement as an effort to raise student achievement. One feature of the SESI discourse is the primacy it gives to institutional leadership, which is credited as being 'second only to classroom teaching as an influence on pupil learning' (Leithwood 2006, p. 3). This section, then, considers how school leaders can exert this influence by using professional development as a means of raising student achievement.

\section{The CPD 'app'}

As stated in the previous section, professional development is 'complex and multidimensional' - yet there is a tendency for it to be viewed reductively. Three metaphors for teacher learning are participation, construction and acquisition (Gewirtz et al. 2009, p. 157). While the first two reflect social theories of learning and a democratic approach to professionalism, the latter - acquisition - presents a deficit view of professional development, which lends itself to CPD add-ons, plug-ins or 'apps', to use metaphors from technology (such offerings are sometimes presented to teachers in a kind of CPD 'Argos catalogue'). Hodkinson associates this approach to professional development with a managerialist 'audit culture' (in Gewirtz et al. 2009), which is consistent with the idea of the school leader as the grand manipulator of inputs in a rational system, coordinating school improvement by applying 'CPD apps' to teacher deficits. This position is advanced in an earlier paper by Pedder and Opfer, which criticises a 'lack of integration in schools' performance management and CPD systems' (2010, p. 444). West-Burnham et al. (2001) situate performance management within the trend towards external criteria for standards (cf. Evans 2011), evaluating teachers according to an 'economic model based on measurable outcomes rather than a professional model judged on what might be termed moral or ethical criteria' (West-Burnham et al. 2001, p. 6). Brief attention will now be given to the acquisition approach to professional development for school improvement.

According to this paradigm, school leaders can exert a direct impact upon teachers' professional development, and consequently should strategically plan CPD opportunities, to balance and align individual, organisational and national needs and priorities for development (Pedder and Opfer 2010). School leaders should also consider the school-level factors that facilitate professional development, including teachers' participation in decisionmaking; a clear vision; support for professional development (through flexible timetabling and the encouragement of experimentation); and the auditing of knowledge and skills (in Pedder and Opfer 2010). In criticism of current CPD practices in schools, Pedder and Opfer (2010) identify a lack of evaluation of CPD activities against desired outcomes; such activities are commonly judged by participants' satisfaction, rather than their impact on students' learning. According to my interpretation of school improvement (presented above), CPD that satisfies teachers but does not lead to improved student achievement does not constitute school improvement. Equally, according to my current definition, professional development is not a sufficient condition for school improvement: a teacher may improve his or her practice by finding a more efficient way to mark exercise books, but if this does not improve student achievement then it does not constitute school improvement.

The rational approach to planning CPD discussed above relates primarily to what Eraut (2004) terms 'deliberative learning', ignoring unconscious 'implicit' opportunities for 
professional development, as well as reactive, serendipitous opportunities. Following an intensive study of selected teachers working in the United Kingdom, Brown and Mclntyre (1993) conclude that although in-service teacher education commonly takes a deficit approach, 'aimed at overcoming teachers' perceived weaknesses', this is both offensive to teachers and - more importantly - inherently 'ineffective' (1993, p. 114). Explanations for the inefficacy of this approach include its demoralising focus on inadequacies, lack of building from present strengths, discouragement for teachers' self-analysis, and tendency to foster an atmosphere of privatism and 'closed doors'. Brown and Mclntyre suggest that professional development could be more productively fostered by focusing and building on strengths, and encouraging collaboration 'within subject or age-range specialisms or across these boundaries, and either in an open-ended exploratory way, or with a deliberate intent about a specific [area]' (1993, p. 115). This position, then, recognises deliberative learning as well as the less focused, serendipitous learning that can occur in the workplace. Brown and McIntyre's recommendations have been advanced in the last two decades through the movement to shape schools as 'professional learning communities' (PLCs).

\section{Professional learning communities and the learning organisation}

The idea of the PLC is a development of work in schools by Senge (2000) and others, and the notion that the school itself should be a learning organisation 'in which pupil learning is inseparable from professional learning and the culture is one in which learning flows across boundaries of role and status' (MacBeath and Dempster 2009, p. 7). This places the PLC very much within the 'democratic' discourse of professionalism posited in opposition to managerialism (Day and Sachs 2004). While the idea of a PLC is theoretically supported by social learning theory (Lave and Wenger 1991, Wenger 1998), it differs in the sense that communities of practice are seen to develop spontaneously and informally, whereas PLCs may be consciously fostered by school leaders. According to MacBeath and Dempster (2009), everyone should have a stake in school leadership, and the role of a positional educational leader in this context is to provide school-wide 'leadership for learning' through the following principles:

- A focus on learning - for all students and staff.

- An environment for learning - an organisational culture that fosters learning and reflection for all.

- A learning dialogue - in which all stakeholders make connections between leadership and learning.

- Shared leadership - through structures that support participation, collaboration and distributed leadership.

Table 1. Expansive-restrictive environments for teachers' professional development.

\begin{tabular}{|c|c|}
\hline Expansive & Restrictive \\
\hline Close collaboration & Isolated, individualist working \\
\hline $\begin{array}{l}\text { Colleagues mutually supportive of } \\
\text { learning }\end{array}$ & Colleagues obstruct each other's learning \\
\hline $\begin{array}{l}\text { Explicit focus on teacher learning as a } \\
\text { common element of working practices }\end{array}$ & $\begin{array}{l}\text { No explicit focus on teacher leaming, except in } \\
\text { response to crises or top-down initiatives }\end{array}$ \\
\hline $\begin{array}{l}\text { Support for development opportunities } \\
\text { beyond the schoolnational priorities }\end{array}$ & $\begin{array}{l}\text { Opportunities linked to compliance with school/ } \\
\text { national agendas }\end{array}$ \\
\hline
\end{tabular}

The participative, learning-focused environment fostered through such principles is one intended to maximise learning for all. In contrast to the rational approach to school leadership and management previously discussed, the PLC is collaborative and adaptive, facilitating double-loop learning (see Figure 2) through constant dialogue and shared leadership. Supporting this position, Hodkinson (in Gerwitz et al. 2009, p. 165) considers the 
conditions most likely to support teachers' effective professional development. Like Hoyle, she conceptualises these along an expansive/restrictive continuum (see Table 1).

Based on empirical longitudinal case studies of four departments, Hodkinson suggests that features on the expansive side of the spectrum are more conducive to teachers' professional learning. One area to which she gives particular emphasis is an environment in which colleagues are mutually supporting and learn through mentoring others. The area of mutual support and collaboration will now be given further consideration.

\section{School improvement through professional collaboration}

The UK Government previously endorsed coaching, mentoring and peer-networking to promote professional development in schools (Rhodes and Beneicke 2002). A precondition for the effective use of such strategies is a school culture that supports collaborative working relationships. Additionally, Rhodes and Beneicke identify the need for the 'careful selection of individuals as coaches and mentors' (2002, p.302), but argue that there is a general lack of consideration regarding 'implementation issues, desirable working standards and the skill and training requirements of staff responsible for helping colleagues learn' (2002, p. 303). However, given the wide variation in individual learning preferences and conditions, I would argue for caution in applying blanket standards and 'training requirements' for mentors. It should be remembered that there is a tendency for top-down standards to focus on behavioural aspects of professionalism, at the neglect of the attitudinal and intellectual domains (Evans 2011). Standards for mentoring, were they to be developed, would usefully consider the analytical and motivational aspects of mentors' professional development, rather than focusing on behavioural aspects of the role, such as specifying the frequency of mentor/mentee meetings per term, or suggesting checklists for effective sessions.

In terms of appointment, Rhodes and Beneicke argue for the importance of selecting mentors who possess 'personal and professional qualities of the highest order' (2002, p. 304), while Simkins et al. (2006) argue that the appointment of a coach with positional authority could in some ways be seen to limit or threaten the coaching process. While these points seem rational, it is important to critically consider the underlying assumption that coaches and mentors must be 'appointed'. Situated learning theorists (Lave and Wenger 1991, 1999) argue that communities of practice develop naturally through individual and collective participation in a common activity; this suggests that, for a new teacher, all teachers should act as mentor and coach.

These ideas are advanced in recent work by Poekert, who understands teacher leadership as a 'non-supervisory, school-based instructional leader[ship role]' through which 'ongoing, site-based professional development for teachers' can be provided (2012, p. 169). It is predicated on 'influence and interaction, rather than power and authority' (2012, p. 171), and is both a cause and an outcome of professional development. These ideas lend compelling support to the positions of Senge (2000) and MacBeath and Dempster (2009) that the preeminent role of the educational leader and manager is to foster learning organisations, in which all stakeholders are learners and leaders.

Two distinct approaches emerge from the research presented in this section; one is aligned to traditional conceptions of the educational leader guiding (or pulling) teachers towards their vision for school improvement. This approach calls for rational, strategic planning, with teachers' professional deficits addressed through blocks of CPD, and audited through performance management. The second approach recognises complexity within schools and promotes adaptive, organisational learning. Diversity is valued, and every student and teacher has a role in ensuring the school is a learning environment for all. From this perspective the leader or manager does not 'use' professional development for the purpose of school improvement, but fosters an environment in which individuals use their learning as a means of increasing the recognition and achievement of all. 


\section{Conclusion}

This article has considered the nature of professional development, how it occurs in individuals, and how educational leaders and managers can facilitate professional development for the purpose of school improvement.

Although uncertainty remains as to how professional development occurs cognitively in individuals, this is not a significant barrier to the current discussion as social theories of learning provide a compelling explanation of the conditions through which professional development occurs in and among individuals within a community of practitioners. On a practical level, research into PLCs suggests ways forward for educational leaders and managers to foster environments in which individual and organisational learning is optimised through collaboration and shared leadership. Unlike top-down national standards (Evans 2011) and traditional, rational models of leadership (West-Burnham et al. 2001), which have a tendency for valuing measurable, observable behavioural outputs over less tangible attitudinal and intellectual aspects of professional development, PLCs facilitate the balanced development of individuals towards shared goals for school improvement.

\section{References}

Aristotle, Waterfield, R., and Bostock, D., 1999. Physics. Oxford: Oxford University Press. Ball, A.F., 2009. Toward a theory of generative change in culturally and linguistically complex classrooms. American educational research journal, 46 (1), 45-72.

Borko, H., 2004. Professional development and teacher learning: mapping the terrain. Educational researcher, 33 (8), 3-15.

Brown, S.A. and Mclntyre, D., 1993. Making sense of teaching. Buckingham: Open University Press.

Chapman, C., 2012. School effectiveness and improvement research, policy, and practice: challenging the orthodoxy. New York, NY: Routledge.

Coolahan, J., 2002. Teacher education and the teaching career in an era of lifelong learning. OECD Education Working Papers, No. 2, OECD Publishing. http://dx.doi.org/10.1787/ 226408628504.

Davies, B., 2007. Developing sustainable leadership. London: Paul Chapman Publishing. Day, C., 1993. Reflection: a necessary but not sufficient condition for professional development. British educational research journal, 19 (1), 83-93.

Day, C. and Sachs, J., 2004. International handbook on the continuing professional development of teachers. Maidenhead: Open University Press.

Eraut, M., 1994. Developing professional knowledge and competence. London: Falmer Press.

Eraut, M., 2004. Informal learning in the workplace. Studies in continuing education, 26 (2), 247-273.

Evans, L., 2008. Professionalism, professionality and the development of education professionals. British journal of educational studies, 56 (1), 20-38.

Evans, L., 2011. The 'shape' of teacher professionalism in England: professional standards, performance management, professional development and the changes proposed in the 2010 White Paper. British educational research journal, 37 (5), 851-870.

Fraser, C., et al., 2007. Teachers' continuing professional development: contested concepts, understandings and models. Journal of in-service education, 33 (2), 153-169.

Friedman, A. and Phillips, M., 2004. Continuing professional development: developing a vision. Journal of education and work, 17 (3), 361-376.

Fullan, M., 2007. The new meaning of educational change. New York: Teachers College Press. 
Gewirtz, S., et al., eds., 2009. Changing teacher professionalism: international trends, challenges, and ways forward. Abingdon: Routledge.

Guskey, T., 2002. Professional development and teacher change. Teachers and teaching, 8 (3), 381-391.

Haigh, N., 2005. Everyday conversation as a context for professional learning and development. International journal for academic development, 10 (1), 3-16.

Hartree, A., 1984. Malcolm Knowles' theory of andragogy: a critique. International journal of lifelong education, 3 (3), 203-210.

Hoekstra, A., et al., 2007. Experienced teachers' informal learning from classroom teaching. Teachers and teaching, 13 (2), 191-208.

Johnson, D. and Maclean, R., 2008. Teaching: professionalization, development and leadership. Dordrecht: Springer.

Kelly, P., 2006. What is teacher learning? A socio-cultural perspective. Oxford review of education, 32 (4), 505-519.

Knowles, M.S., 1984. Andragogy in action. San Francisco, CA: Jossey-Bass.

Lave, J. and Wenger, E., 1991. Situated learning: legitimate peripheral participation.

Cambridge, UK: Cambridge University Press.

Lave, J. and Wenger, E., 1999. Learning and pedagogy in communities of practice. In:

J. Leach and B. Moon, eds. Learners and pedagogy. London: Paul Chapman in association with Open University, 21-33.

Leithwood, K.A., 2006. Seven strong claims about successful school leadership [online]. Nottingham: NCSL. Available from: http://dera.ioe.ac.uk/6967/ [Accessed 21 February 2013].

Lumby, J., Crow, G., and Pashiardis, P., 2008. International handbook on the preparation and development of school leaders. New York, NY: Routledge.

MacBeath, J.E.C. and Dempster, N., 2009. Connecting leadership and learning: principles for practice. London: Routledge.

Mortimore, P., 1999. Understanding pedagogy and its impact on learning. London:

Chapman.

Ofsted, 2010. School Inspection Report (Mossbourne Community Academy) [online].

Available from: http://www.ofsted.gov.uk/inspection-reports/find-inspection-report/provider/

ELS/134693 [Accessed 21 February 2013].

Opfer, V.D. and Pedder, D., 2011. Conceptualizing teacher professional learning. Review of educational research, 81 (3), 376-407.

Pedder, D. and Opfer, V.D., 2010. Planning and organisation of teachers' continuous professional development in schools in England. The curriculum journal, 21 (4), 433-452.

Poekert, P.E., 2012. Teacher leadership and professional development: examining links between two concepts central to school improvement. Professional development in education, 38 (2), 169-188.

Rhodes, C. and Beneicke, S., 2002. Coaching, mentoring and peer-networking: challenges for the management of teacher professional development in schools. Journal of in-service education, 28 (2), 297-310.

Senge, P.M., 2000. Schools that learn: a fifth discipline fieldbook for educators, parents, and everyone who cares about education. New York, NY: Doubleday.

Simkins, T., et al., 2006. Coaching as an in-school leadership development strategy: experiences from Leading from the Middle. Journal of in-service education, 32 (3), 321-340.

Slee, R., Weiner, G., and Tomlinson, S., 1998. School effectiveness for whom?: challenges to the school effectiveness and school improvement movements. London: Falmer Press. Stevenson, A., ed., 2010. Oxford dictionary of English [online]. Oxford: Oxford University Press. Available from: http://0-www.oxfordreference.com.wam.leeds.ac.uk/views/ ENTRY.html?subview=Main\&entry=t140.e0664700 [Accessed 17 February 2012]. Ushie, B.C., 2009. Partnership learning: an imperative for the continuing professional development of primary school teachers in Nigeria. Professional development in education, 35 (2), 285-287. 
Villegas-Reimers, E., 2003. Teacher professional development: an international review of the literature. París: International Institute for Educational Planning.

Wenger, E., 1998. Communities of practice: learning, meaning, and identity. Cambridge, UK: Cambridge University Press.

West-Burnham, J., O'Neill, J., and Bradbury, I., 2001. Performance management in schools: how to lead and manage staff for school improvement. Harlow: Pearson Education.

Whitty, G., 2000. Teacher professionalism in new times. Journal of in-service education, 26 (2), 281-295.

Zwart, R.C., et al., 2007. Experienced teacher learning within the context of reciprocal peer coaching. Teachers and teaching, 13 (2), 165-187. 